\title{
How Korean Venture Capitals Invest In New Technology Ventures*
}

\section{Youngkeun Choi**}

\begin{abstract}
In the entrepreneurship field, this study examines what kinds of external endorsements are helpful for venture capitals investment and the growth of new technology ventures in developing countries. This study uses the signalling theory and the methodologies of multiple regression and survival analysis with the panel data of the ventures in Korea. In the results, collaboration with business groups and certification of government are positively influential in attracting venture capitals' investment, which accelerate the growth of new technology ventures. The practical implication for entrepreneurs is that they need to obtain the endorsement from business groups and governments strategically.
\end{abstract}

Keywords: new technology venture creation, small business, signalling theory, business group, venture capital, Initial Public Offering.

\section{Introduction}

Developing countries need to strengthen their research capabilities in order to catch up with advanced countries. For this, a country's activities to develop, adapt and harness its innovative capacity are critical for its economic performance in the long run (Ernst, 2005; Ernst and Naughton, 2008). As new technology-based ventures (NTVs) introduce disruptive technologies and perform the role of Schumpeterian entrepreneurship, or "creative destruction," in the economy, they are an especially important source of new jobs and provide a crucial stimulus to national economies (Audretsch, 1995; Timmons and Bygrave, 1986). So the factors that drive their performances have increasingly attracted the attention of entrepreneurship scholars as well as policy makers in developing countries.

NTVs need a greater amount and variety of resources for research and development (R\&D) and marketing to differentiate and commercialize new technologies compared to traditional businesses. So, it is very important for NTVs to obtain the requisite resources from external resource holders. However, NTVs involve not only uncertainty that general ventures possess

* This research was supported by a 2013 Research Grant from Sangmyung Univesity.

** Assistant Professor, Division of Business Administration, College of Business, Sangmyung University, 20, Hongjimun 2-gil, Jongno-gu, Seoul 110-743, Korea, penking1@smu.ac.kr. 
but also additional uncertainty, for new technology is by its very nature highly uncertain (Tushman and Rosenkopf, 1992). For these reasons, NTVs are extremely risky. Such uncertainty makes resource holders hesitant to provide resources to NTVs, so they have difficulty in obtaining the requisite resources in the markets (Colombo and Grilli, 2007; Peneder, 2008).

A lot of researches have argued that venture capitals are typical resource providers for NTVs and examined what their viewpoints of investment decision-making (Gompers and Lerner, 1997; 2001) are. In developed countries, relatively efficient markets for capital and labour, easy access to complementary business services, and consistent enforcement of property right, as well as relatively corruption-free government and independent judiciary, all permit VCs to provide their resources by the rules of the game. In developing countries, by contrast, many of these institutions exist in a relatively weak form. Therefore, under these different situations, the investment pattern of VCs in developing countries may differ from one of VCs in developed countries such as USA. However, little research has paid its attention to this agenda of how VCs in developing countries invest in NTVs. Based on this gap in the academic literature, the following research question is posed:

$\mathrm{RQ}$ : What factors are attracting VCs whose investments accelerate the growth of NTVs?

\section{Hypothesis}

The present study employs insight from signalling theory (Podolny, 1993; 2008; Spence and Michael, 1974; Spence, 1973). To deepen the research question, this study examines two sub research questions. First, what are the identities of endorsing organization signalling to VCs' investment in developing countries? Second, do VCs play a pivotal role for the growth of NTVs in developing countries? This study then tests these hypotheses using the NTVs in Korea which is a typical example of a developing country. The empirical findings from this study confirm these hypotheses and have important implications for both academicians and practitioners.

External endorsement of NTVs and VC investment in developing country In developed countries, market-based transactions provide access to most needed elements of resources such as finances, human resources, technology etc. Relatively efficient markets for capital and labor, easy access to complementary business services and consistent enforcement of property rights as well as relatively corruption-free government permit individual entrepreneurs to raise capital, hire human resources, learn about customer demands, and play by the rules of the game. In developing countries, by 
contrast, where many of these institutions exist in a relatively weak form, NTVs need to act strategically to gain legitimacy to be endorsed by respectable organizations.

NTVs involve considerable uncertainty. Entrepreneurs try to reduce this uncertainty by gaining legitimacy from well-regarded individuals and organizations. Zimmerman and Zeitz (2002) argued that legitimacy, which connotes a social judgment of acceptance, appropriateness, and desirability, is a resource by itself that enables startups to access other resources needed for survival and growth and helps startups overcome the liability of newness. Although startups can gain legitimacy by conforming passively to the demands and expectations of the existing social structure (DiMaggio and Powell, 1983; Suchman, 1995), they can also do so by acting strategically (Zimmerman and Zeitz, 2002). For instance, startups can choose more favorable environments (Porter, 1980), manipulate their environment by teaming with other successful organizations (Oliver 1991), and create environments with new norms, values, and models (Aldrich and Fiol, 1994). Several studies have found great variance in startups' ability to gain access to resources and stable relationships, which in turn leads to differences in these startups' early performances (Baum, 1996; Fichman and Levinthal, 1991).

Therefore, in developing countries, external endorsement is a critical factor for success in NTVs and can be a positive signal to VCs. Two key respectable organizations, business group (BG) and government, can play a pivotal role to endorse NTVs which would be a positive signal to VCs.

First, strategic alliances with BGs would provide endorsement for NTVs. BGs control a substantial fraction of a country's productive assets and account for the largest and most visible of the country's firms. So they can contribute to innovation through intangible assets such as business reputation and government tie by substituting for functions that standalone institutions provide in developed countries (Teece, 1996). BGs are respectable organizations that can provide various resources including human resources, technology, or markets as well as finance. Therefore, in developing countries, NTVs can obtain their requisite resources by collaborating with BGs (Ratajczak-Mrozek, 2012). And, by establishing a strategic alliance with a highly reputable partner, venture companies can receive the benefit of the reputation and induce resources from the possessors. Stuart et al. (1999) and Stuart (2000) argue that the reputation of strategically allied partners provide the endorsement. Stuart et al. (1999) argue that as the uncertainty of ventures increases, the endorsement effect which strategic alliances provide increases. Furthermore, Chang (2004) shows that in the internet industry, the reputation of the alliance partner of the ventures provides the role of endorsement. Especially, Podolny and Stuart (1995) argue that if BGs adopt 
some new technology, it can be widely used by achieving social recognition. BGs often control a substantial fraction of a country's productive assets and account for the largest and most visible of the country's firms (Granovetter, 1995; Khanna and Palepu, 1997). In particular, unlike in developed countries, because BGs fill the gap left by market failure, they can provide resources for the innovation of ventures and thus influence the survival and growth of ventures. Therefore, due to high uncertainty of NTVs, VCs have difficulties in evaluating the value of NTVs directly and thus are reluctant to provide their resources. Given this situation, collaborations with BGs play the role of endorsement to make VCs positively evaluate the potential of NTVs. This endorsement induces VCs to provide their resources to NTVs and consequently perform well.

Secondly, a variety of support forms from governments would provide endorsement for NTVs. Governments of developing countries trying to catch up with technological advancement have a legitimate incentive to seriously consider socioeconomic externalities of sponsoring NTVs. Thus they often intervene in the market for corporate creation and development. Studies in financial economics argue that due to capital market imperfections, it is difficult for NTVs to obtain the external financing they need; in turn lack of adequate funds hinders firms' growth and even threatens their survival (Carpenter and Petersen, 2002a and Carpenter and Petersen, 2002b). Under the situation of capital market imperfections, the government provides R\&D fund directly to early-staged NTVs, in which VCs are reluctant to invest, to maximize socioeconomic externalities of them (Griliches, 1998; Lach, 2000). For example, Tan and Tay (1994) investigated the factors that influence the growth of small firms and suggested that financial support from the government was major a factor. Therefore, in developing countries, NTVs can obtain their requisite resources through supports of governments. And by obtaining supports from governments, venture companies can receive the benefit of the reputation and induce resources from the possessors. Lerner (1999) suggests the government support plays the role of endorsement. He found that the firms that receive SBIR obtain more investment of VCS than other firms. An even more interesting thing is that the amount of support is not important but the support itself provides the positive signal of endorsement. Unfortunately, there is no other research apart from Lerner (1999)'s study that suggests the role of endorsement of the government's support. In particular, unlike in developed countries, because governments fill the gap left by capital market imperfections, they can provide resources for the innovation of ventures and thus influence the survival and growth of ventures. Therefore, due to high uncertainty of NTVs, VCs have difficulties in evaluating the value of NTVs directly and thus are reluctant to provide 
their resources. Given this situation, supports from governments play the role of endorsement to make VCs positively evaluate the potential of NTVs. This endorsement induces VCs to provide their resources to NTVs and consequently perform well.

H 1: When NTVs are endorsed by respectable organizations, venture capitals in developing countries are more likely to invest in them.

H 1-1: When NTVs collaborate with business groups, venture capitals in developing countries are more likely to invest in them.

H 1-2: When NTVs obtain supports from governments, venture capitals in developing countries are more likely to invest in them.

\section{The mediating role of venture capitals' investment of NTVs' growth}

As resource providers, VCs are helpful for ventures. Gompers and Lerner $(1997 ; 2001)$ argue that VCs provide financial resources needed for ventures and their portfolios can grow faster, for they can get additional investment from VCs and they are not in financial trouble. And, Davila et al. (2003) argues that ventures that receive more funding are able to hire, retain, and pay talented employees, who are critical to ventures' growth and help them go to an IPO more quickly. Baum and Silverman (2004) suggest that VCs are not only investors but also allegedly perform an important "coach" function. They provide their portfolios with constant services in fields such as: strategic planning, marketing, finance, accounting and human resource management, where these firms typically lack internal capabilities.

Simultaneously, other resource holders can view VCs' investment as a strong signal of ventures' quality and future prospects (Spence and Michael, 1974; Freeman, 1999; Podolny, 2001; Stuart, et al. 1999). VCs are evaluated on their ability to generate high returns for their investors. Since they take a fraction of the proceeds, they are motivated to generate high performance. Moreover, VCs that have a history of delivering extraordinary returns find it easier to raise funds from investors. Thus, VCs are unlikely to invest in ventures that have poor future prospects. In addition, since VCs often help ventures by performing "coach" function, they increase the chance that ventures become successful. Thus, endorsement by respectable VCs not only signals the quality of a venture but also serves as a vote of confidence in the venture. By doing so, the endorsing organizations' legitimacy carries over to the recipient, providing it credibility, contact, and support for the entrepreneurs, building a venture's image, which in turn, other resource holders will provide their resources actively (Spence, 1974; Freeman, 1999; Podolny, 2001). Megginson and Weiss (1991) maintain that VC-backed ventures go public faster than the non-VC-backed one. Chang (2004) argues that the higher the reputation of 
ventures, the more money internet ventures raise from VCs, the faster they have an IPO.

As I review the relevant literatures, the endorsement of respectable organizations would influence the growth of NTVs (Khandwalla ,1976; Utterback and O'Neill, 1994; Kirzner, 1997; McMullen and Shepherd, 2006; Weick, 1996; Stuart, et al. 1999; Stuart, 2000; Chang, 2004; Podolny and Stuart, 1995; Tan and Tay, 1994; Lerner, 1999). This study suggests that they lure investment of VCs in developing countries. And relevant studies maintain that VCs provide their tangible and intangible resources to NTVs and induce passive resource holders to provide their resources, and so in turn NTVs can acquire the necessary resources they need to perform well. Therefore, this study raises the possibility of a mediating role of VCs between the endorsement of respectable organizations and the growth of the NTV.

H 2: NTVs endorsed by respectable organizations can grow faster when they receive venture capitals investments.

H 2-1: NTVs collaborating with business groups can grow faster when they receive venture capitals investments.

H 2-2: NTVs obtaining supports from governments can grow faster when they receive venture capitals investments.

\section{Methods}

Sample

I collected the data in the following procedure. First, data is collected from DART (Data Analysis, Retrieval and Transfer System), which is an electronic disclosure system that allows companies to submit disclosures online (www.dart.fss.or.kr). Second, the original target research sample consists of 1,253 KOSDAQ (Korea Securities Dealers Automated Quotation) stock market listed firms from July 1, 1996 to December 31, 2005. Finally, I supplemented the database with diverse approaches such as newspaper articles, publications, corporate homepages and phone calls to the firms.

And, to define our final sample for analysis, I had to consider the following things. First, I limited samples to IT firms founded after 1990, because business ventures in Korea have developed as the IT industry has expanded quickly during 1990s (Chung and Choi, 2008). Second, I also limited samples to the firms which went public after July 1, 2000 to eliminate the unusual bias caused by these dramatic changes in market conditions. The Korean government had consistently loosened the listing requirements for the KOSD AQ market to encourage the provision of listed firms from July 1996 when the KOSDAQ stock market opened. But, by the early 2000s, the KOSDAQ market had collapsed. With rapid market readjustment, IT firms faced a dramatic drop 
in stock prices. Internet companies were hit hardest elsewhere. Moreover, market factors were aggravated due to insufficient restructuring, misdeeds of venture managers and unfair trading in the KOSDAQ market. With the overall venture industry experiencing a dramatic shakeout, the government raised the registration standards for the KOSDAQ market (Lee 2002). The KOSDAQ market was under-valued from July 1, 1996 to late 1998 due to the so called "IMF financial crisis" and the bursting of the dot-com stock market bubble from early 1999 to the first half of 2000. Finally, I eliminated firms of which the CEO is not a founder or a major shareholder. This study came up with the final sample of 170 KOSDAQ-listed firms for analysis.

\section{Analysis method}

Logistic regression was employed to test Hypotheses 1 and 2. I added the VC's investment as a dependent variable. I conducted logistic regression because the dependent variable is measured not on a quantitative scale, but on a qualitative scale. The binary variable of VC's investment follows binominal distribution, not normal distribution.

And finally, survival analysis was employed to test Hypotheses 3 and 4. I use the time to IPO as a dependent variable. a longitudinal statistical analysis method may be used both in the analysis of qualitative and quantitative data (Tuma and Hannan 1984). The dependent variable of this analysis method is the time to the occurrence of an event or the rate of an event occurring that a researcher is interested in. This study adopts the Cox Regression Model, which is a widely used statistical model to investigate the complex relationship between survival time and other factors.

\section{Measures}

\section{Independent variables}

\section{Collaboration with a $B G$}

Korean commercial law defines about 900 firms with assets of over 2 trillion Won as a business group. More generally, they regard the 30 largest firms ranked by assets as so called 'Chaebols', announced by the Fair Trade Commission from 1995 to 2005. Collaboration with a BG includes supply agreements, joint R\&D, share participation, and joint ventures. I define large companies as the 30 largest firms ranked by assets. This research defines a BG as an enterprise among the 30 largest firms as declared by the Fair Trade Commission. This study uses a binary variable to measure a strategic alliance with a BG that takes on the value of 1 if allied with BGs (strategic alliance with $B G=1$ ) and 0 otherwise (no strategic alliance with $B G=0$ ). 


\section{Government Support}

In the research context, Korean government provided some support program of venture company certification. Under the venture company certification program enacted in 1998, the Small and Medium Business Administration designates qualified venture companies as 'official venture company' based on the stipulated regulations. This certification system is based on the 'Special Law for the Promotion of Venture Businesses.' This is quite a unique institution because there is no similar legislation case in the other countries. Korean government provides certified venture companies with various benefits such as tax benefits, generous stock option issues, extended guarantee by government owned financial institution, preferred supplier status for government purchase, alleviated public stock offering requirements, and so forth. This study uses binary variable to measure the firm obtained venture company certification that takes on the value of 1 if received venture company certification (venture company certification $=1$ ) and 0 otherwise (non-venture company certification $=0$ ).

\section{Mediating variables}

\section{Venture capital investment}

Previous research suggested that the investment of VC affects the time to IPO. Gompers and Lerner $(1997 ; 2001)$ argue that venture firms that have obtained VC investment go public faster than firms without VC investment. Venture firms endorsed by VC can secure additional financial resources at the proper time, thus they can grow relatively fast. In addition, venture firms endorsed by VC attain rapid growth, because VC often helps venture firms by providing non-financial resources such as marketing support, managerial advice, human resources supply, and alliance arrangements with potential customers and suppliers, all of which can increase the chance that these startups become successful. An endorsement by a respectable VC investor also signals the quality of a venture firm. By doing so, the endorsing organization's legitimacy carries over to the recipient, providing it credibility, contact, and support for the founders, building a start-up's image, and facilitating the startup's access to resources. Therefore, the reputation of VC helps venture firms go to IPO faster (Gompers 1996; Yoon et al. 2005). This study uses a binary variable to measure $\mathrm{VC}$ support that takes on the value of 1 if it received VC $(V C$ investment $=1$ ) and 0 otherwise (no VC investment $=0$ ).

\section{Dependent variables}

\section{The growth of NTVs}

NTVs exploit business opportunities with differentiated technology in areas of rapid technological change. NTVs are under a higher level of 
uncertainty than existing firms, thus, they lack sufficient financial resources for R\&D and marketing compared to existing firms. An IPO allows a firm to tap a wide pool of investors to provide it with capital for future growth, repayment of debt, and/or working capital. And once a firm is listed, they are able to enhance their reputation by introducing the firm's value outside of the firm. But, IPO firms sometimes exhibit a decline in post-issue operating performance because there is potential for higher agency conflicts, lower ownership retention, and IPO expenses (Jain and Kini, 1994). Despite these drawbacks, NTVs have no choice but to implement IPOs as a crucial strategy and try to reduce the time required to IPO. Researchers thus adopt the IPO event as a measure for the rate of the NTVs' growth (Chang, 2004; Stuart, et al., 1999). The time to IPO is measured by months since the date of founding. This study takes the logarithm of this variable for the adjustment of scale.

\section{Control variables}

Industry sub-type characteristics

Characteristics of industry sub-types affect venture firm's time to IPO (Chang, 2004; MacMillan, et al., 1985; Stuart, et al., 1999). The market stage also influences alliance formation (Eisenhardt and Schoonhoven, 1996). I defined an IT firm as the firm which was assigned an IT index when listed on KOSDAQ. IT KOSDAQ index classifies communications and broadcasting, IT software, and IT hardware. Communications and broadcasting includes communications services and broadcasting services. IT software covers internet, software, computer services, and digital contents whereas IT hardware covers communications equipment, IT equipment, semiconductor, and components.

\section{Stock Market Conditions}

Stock market conditions influence the time to IPO (Chang, 2004; Stuart, et al., 1999). Founders and financial investors tend to decide to go public because high subsequent investment returns are expected from the buoyant stock market for IPOs. The IPO process in Korea usually takes 3 months. This study thus measures the stock market condition as the composite stock exchange index of KOSDAQ from 3 months before the IPO date.

\section{Firm Size}

This study controls the firm size. Firm size is used to account for the greater resources and choices available to larger firms with a greater ability to invest in technology and innovation as well as potential scale advantages (Scherer and Ross, 1990). This study measures firm size as the log (10) of yearly sales just before the IPO. 


\section{Human capital}

Human capital theory maintains that knowledge provides individuals with increases in their cognitive abilities, leading to more productive and efficient potential activity (Schultz, 1959; Becker, 1964; Mincer, 1974). Two key demographic characteristics such as formal education and previous work experience underlie the concept of human capital (Becker, 1964). a founder's level of formal education is calculated based on a classification of the founder's information according to two levels. The higher level is a master's or doctorate degree. The lower level is an undergraduate degree or lower. The previous work experience takes on the value 1 if a founder has worked in a related industry before and 0 otherwise. The functional background takes on the value 1 if a founder's undergraduate major or career experience is in output functions and 0 otherwise.

\section{Results}

Descriptive statistics and correlations

Table 1 presents means, standard deviations, and correlations for the measures. VIFs (variance inflation factors) for all the regression models are less than 2, which are well below the guideline of 10 recommended (Chatterjee and Hadi, 2006).

Table 1 Descriptive statistics and correlations

\begin{tabular}{|c|c|c|c|c|c|c|c|c|c|c|c|c|c|}
\hline & Variables & Mean & SD & 1 & 2 & 3 & 4 & 5 & 6 & 7 & 8 & 9 & 10 \\
\hline 1 & IT software & .47 & .50 & & & & & & & & & & \\
\hline 2 & IT hardware & .49 & .50 & $-.93 * *$ & & & & & & & & & \\
\hline 3 & $\begin{array}{l}\text { Communications and } \\
\text { broadcasting }\end{array}$ & .04 & .19 & $-.18^{*}$ & $-.19 *$ & & & & & & & & \\
\hline 4 & KOSDAQ market index & 705.41 & 232.91 & .10 & -.09 & -.02 & & & & & & & \\
\hline 5 & Yearly sales before IPO & 315.73 & 368.38 & -.04 & .09 & -.13 & -.03 & & & & & & \\
\hline 6 & Level of education & .29 & .46 & -.13 & .11 & .05 & -.06 & .02 & & & & & \\
\hline 7 & $\begin{array}{l}\text { Related industry } \\
\text { experience }\end{array}$ & .45 & .50 & .01 & .01 & -.04 & -.09 & -.10 & .01 & & & & \\
\hline 8 & $\begin{array}{l}\text { Alliance with a business } \\
\text { group }\end{array}$ & .51 & .50 & .01 & .02 & -.07 & -.10 & -.07 & -.07 & $.34 * *$ & & & \\
\hline 9 & Venture certification & .56 & .50 & -.04 & .07 & -.09 & -.07 & -.09 & -.09 & $.20 * *$ & $.22 * *$ & & \\
\hline 10 & VC investment & .75 & .43 & $.18^{*}$ & -.13 & -.14 & -.10 & -.11 & -.09 & $.33^{* *}$ & $.47^{* *}$ & $.49 * *$ & \\
\hline 11 & Time to IPO & 6.20 & 2.46 & -.10 & .04 & $.17^{*}$ & .05 & .04 & .06 & $-.31 * *$ & $-.65 * *$ & $-.36 * *$ & $-.50 * *$ \\
\hline
\end{tabular}

$\mathrm{n}=170, * \mathrm{p}<.05 ; * * \mathrm{p}<.01$ 
The features of the sample firms are described as follows. The yearly sales just before the IPO are 315 billion won on average and we can define those firms are SMEs. In the IT industry, less than $1 \%$ of firms are in communications and broadcasting, $47 \%$ of the firms are in the IT software (internet, software, computer services, and digital contents), and $49 \%$ of the firms are in IT hardware (communications equipment, IT equipment, semiconductors, and components). The founders with a master's or doctoral degree constitute $29 \%$, and with related industry experience $45 \% .51 \%$ of the firms had alliances with BGs and $56 \%$ of the firms are certified as venture companies. $75 \%$ of the firms obtained VCs investment. The dependent variable, the time to IPO, it is 6.2 years on average.

\section{Main analysis}

To test the hypothesis, the present study adopts the four steps of Baron and Kenny (1986). Baron and Kenny (1986) suggest four steps to establish mediation. Step 1 requires that the independent variable is significantly related to the dependent variable; step 2 requires that the independent variable is significantly related to the mediator; step 3 requires that the mediator affects the dependent variable while controlling for the effect of the independent variable. And finally, when these conditions are satisfied, step 4 requires that the effect of the independent variable on the dependent variable is insignificant when controlling for the mediator in order to indicate complete mediation; otherwise partial mediation is indicated. The effects in both steps 3 and 4 are estimated in the same regression equation.

Model 1 tests the relationship between independent variables and firms' growth which explain control variables, independent variables, and the dependent variable of time to IPO. Among the control variables, relatedindustry experience of an entrepreneur $(p<.01)$, BG collaboration $(p<.01)$ and venture certification $(p<.01)$ are negatively significant to time to IPO.

Table 2. Results of regression analyses

\begin{tabular}{lccc}
\hline & $\begin{array}{c}\text { Model 1 } \\
\text { Time to IPO }\end{array}$ & $\begin{array}{c}\text { Model 2 } \\
\text { VC's } \\
\text { investment }\end{array}$ & $\begin{array}{c}\text { Model 3 } \\
\text { Time to IPO }\end{array}$ \\
\hline $\begin{array}{l}\text { Constant } \\
\text { Control }\end{array}$ & $-3.098^{* *}$ & \\
IT S/W & -.119 & $1.395^{* *}$ & -.010 \\
IT H/W(ref) & .418 & -.548 & .255 \\
Communications and broadcasting & -1.055 & & .015 \\
KOSDAQ index & .499 & & 1.184 \\
Sales & & & \\
\hline
\end{tabular}




\begin{tabular}{lccc}
\hline High academic degree & -.021 & -.127 & -.031 \\
Prior experience in a related industry & $-.382^{* *}$ & $.955^{*}$ & $-.348^{*}$ \\
& & & \\
Independent variable & & & \\
BG collaboration & $-1.627^{* *}$ & $2.010^{* *}$ & $-1.563^{* *}$ \\
Venture certification & $-.616^{* *}$ & $2.372^{* *}$ & $-.320^{*}$ \\
Mediating variable & & & \\
VC investment & & & $-.666^{* *}$ \\
\hline-2 Log Likelihood & 1303.463 & 145.120 & 1293.539 \\
Chi-square & $119.849^{* *}$ & & $127.989^{* *}$ \\
Cox and Shell $\mathrm{R}^{2}$ & & .409 & \\
\hline
\end{tabular}

$\mathrm{n}=170, * \mathrm{p}<.05 ; * * \mathrm{p}<.01$

Model 2 tests the relationships stated in Hypotheses 1-1 and 1-2, explaining the dependent variable of VC's investment. IT S/W and Relatedindustry experience of an entrepreneur in control variables are positively significant to VC's investment, BG collaboration $(p<.01)$ and venture certification $(p<.01)$ are positively significant to VC's investment. However, the relationship between level of education of an entrepreneur and VC's investment is not significant. Therefore, Hypotheses 1-2 and 1-2 are supported.

In the final step of the mediation analysis, the growth of NTV was regressed on independent variables, VC's investment, and the control variables. Model 3 indicates that the negatively significant relationship $(\beta=-1.627, p<.01$ between BG collaboration and time to IPO becomes weaker $(\beta=-1.563$, $p<.01)$ when the alliance with VCs' investment is entered into the equation $(p<.01)$. The negatively significant relationship $(\beta=-.616, p<.01$ between venture certification and time to IPO becomes weaker $(\beta=-.320, p<.01)$ in the same manner. As a conclusion, VC's investment has a partial mediating effect. Thus, hypotheses 2-1 and 2-2 are supported.

\section{Discussions}

The purpose of this study is to examine how VCs in developing countries invest in new technology ventures. The core of tested models can be recapitulated as follows: (1) the endorsements by respectable organizations influence the likelihood of VCs' investment; and (2) VC's investment may have mediating effects on the relationship between the endorsements by respectable organizations and NTVs' growth. In the results, collaboration with BGs and 
certification of government are positively associated with NTVs' obtaining VC's investment. And VC's investments are helpful for the growth of NTVs.

The research contribution of this study is to expand the entrepreneurship research field by developing and testing a mediating model that provides an explanation of the NTV performance relationship in the context of developing countries. From a signalling theory perspective, it is important to understand the resource providers which lure VC's investment as a linkage between external endorsement and the NTV growth in a developing country.

And, the results of this study provide practical implications to the entrepreneurs of NTVs and policy makers in developing countries. First, because there is market failure in developing countries, VCs judge the endorsement by BGs and government as an important factor for their investment decision making. Therefore, entrepreneurs of NTVs in developing countries should collaborate with BGs or get certification form government strategically. And policy makers in developing countries should introduce the relevant policy that can give a variety of incentives to BGs which collaborate with NTVs and should build up the certification system to select the promising NTVs.

Nevertheless, this study has some limitations. I adopt time to IPO as a measure for venture performance. Related research measures the time to IPO as the indicator of NTV's growth (Chang, 2004; Deeds, et al., 1997a; 1997b; Stuart, et al., 1999). I believe this event is a meaningful interim measure of an NTV performance because plenty of financial resources are required to maintain venture firm consistency. This measure is not perfect since not all the ventures decide to go public. Thus, I acknowledge the limitation in using time to IPO as a performance indicator. In the future, using diverse dependent variables would significantly improve our understanding on the signalling mechanism of external endorsement. This study adopts time to IPO as a dependent variable to investigate the signalling effect of external endorsement. Prior research measuring NTV performance with market value in the process of IPO as well as time to IPO (Stuart, et al., 1999) has shown that the influence of resource holders signalling mechanism on time to IPO and firm value evaluation are differentiated. Time to IPO is a firm performance indicator and this suggests that for resource holders who provide resources for firm growth it may serve an important role as a signal of promising performance in the growth stage of ventures, while market value at IPO can be used to measure how the ventures are valued in the IPO process. Prior studies argue that underwriters, institutional investors and individual investors act as a signal and so influence market value at IPO (Megginson and Weiss, 1991; Podolny, 1993). These signalling effects may be helpful to new ventures that have not yet proven to be viable. Further study is thus 
necessary in order for us to understand the exact nature and extent of these relationships.

This study also encourages future research to identify the role of endorsement by government support in other types and countries. Many governments are keenly interested in nurturing their new ventures as they can create new employment, develop new technology, and contribute to national economic growth (Acs and Audretsch, 1990). Due to these positive externalities coming from the promotion of new business start-ups, the government needs to distribute more resources to new start-ups than free markets typically do. Namely, because venture capitalists make their commitments for a capital gain, they are not concerned with positive socioeconomic externalities. Recently, the governments in advanced countries provide more indirect supports in regulation, policy, and certification rather than direct ones financially (USSA, 1995; OECD, 1997). The governments have limited resources but are interested in maximizing the effect of distributing more resources to promising firms. Therefore, they try to find indirect supports to play the role of endorsement to induce other resource holders to provide their resources favorably. Research finding this issue will be helpful for the governments which are considering indirect support.

\section{References}

Acs, Z., Audresch, D. B. (1990). Innovation and small firms. Cambridge: MIT Press.

Aldrich, H., Fiol, M. (1994). Fools rush in? The institutional context of industry creation. Academy of Management Review, 19, 645-670.

Audretsch, D.B. (1995). Innovation and industry evolution. Cambridge: The MIT Press.

Baron, R. M., Kenny, D. A. (1986). The moderator-mediator variable distinction in social psychological research: Conceptual, strategic, and statistical considerations. Journal of Personality and Social Psychology, 51(6), 1173-1182.

Bates, T. (1995). Self-employment entry across industry groups. Journal of Business Venturing, 10(2), 143-56.

Baum J, Silverman B. (2004). Picking Winners or building them? Alliance, intellectual, and human capital as selection criteria in venture financing and performance of biotechnology startups. Journal of Business Venturing, 19(3), 411-436.

Becker, G. S. (1964). Human Capital: a Theoretical and Empirical Analysis. Columbia University Press: New York.

Bruderl, J., Preisendorfer, P., Ziegler, R. (1992). Survival chances of newly founded business organizations. American Sociological Review, 227-242. 
Baum, J. (1996). Organizational ecology. In: Clegg, S., Hardy, C., Nord, W. (Eds.), Handbook of Organization Studies (pp. 77-114). London: Sage Publications.

Carpenter R. E., Petersen B. C. (2002a). Capital market imperfections, hightech investment, and new equity financing. Economic Journal, 112, 54-72.

Carpenter R. E., Petersen B. C. (2002b). Is the growth of small firms constrained by internal finance? The Review of Economics and Statistics, 84, 298-309.

Castanias, R. P., Helfat, C. E. (1991). Managerial resources and rents. Journal of Management, 17(1), 155-171.

Chang, S. J. (2004). Venture capital financing, strategic alliances, and the initial public offerings of internet startups. Journal of Business Venturing, 19(5), 721-741.

Chatterjee, S., Hadi, A. S. (2006). Regression analysis by example. New Jersey: John Wiley and Sons.

Cohen, W. M., Daniel A. L. (1990). Absorptive capacity: a new perspective on learning and innovation. Administrative Science Quarterly, 35, 128-152.

Colombo, M. G., Grilli, L. (2007). Funding gaps? Access to bank loans by hightech start-ups. Small Business Economics, 29(1), 25-46.

Deeds, D., Mang, P., Frandsen, M. (1997a). The impact of firm-specific capabilities on the amount of capital raised in an initial public offering: evidence from the biotechnology industry. Journal of Business Venturing, 12, 31-46.

Deeds, D., Mang, P., Frandsen, M. (1997b). The quest for legitimacy: a study of biotechnology IPO's. Frontiers of Entrepreneurial Research, 533-543.

DiMaggio, P., Powell, W. (1983). The iron cage revisited: institutional isomorphism and collective rationality in organizational field. American Sociology Review, 48, 147-160.

Eisenhardt, K. M., Schoonhoven, C. B. (1996). Resource-based view of strategic alliance formation: Strategic and social effects in entrepreneurial firms. Organization Science, 136-50.

Ernst, D. (2005). Pathways to innovation in Asia's leading electronics-exporting countries-a framework for exploring drivers and policy implications. International Journal of Technology Management, 29(1), 6-20.

Ernst, D., Naughton, B. (2008). China's emerging industrial economy: Insights from the IT industry. London: New York: Routledge.

Fichman, M., Levinthal, D. (1991). Honeymoons and the liabilities of adolescence: a new perspective on duration dependence in social and organizational relationships. Academy of Management Review. 16, 442-468.

Freeman, J. (1999). Venture capital as an economy of time. In Leenders RTAJ, Gabbay S (Eds.), Corporate Social Capital and Liability (pp.460-482), Norwell, MA. Kluwer Academic Publisher. 
Gompers, P. A., Lerner, J. (1997). Risk and reward in private equity investments: the challenge of performance assessment. Journal of Private Equity, 1(2), 5-12.

Granovetter, M. S. (1995). Getting a job: a study of contacts and careers. Chicago: University of Chicago Press.

Green, P. G., Brush, C. G., Hart, M. M. (1999). The corporate venture champion: a resource-based approach to role and process. Entrepreneurship Theory and Practice, 23, 103-122.

Griliches, Z. (1998). R\&D Productivity. University of Chicago Press: Chicago, IL.

Guthrie, J. P., Grimm, C. M., Smith, K. G. (1991). Environmental change and management staffing: An empirical study. Journal of Management, 17(4), 735-748.

Henderson, R., Cockburn, L. (1994). Measuring competence? Exploring firm effects in pharmaceutical research. Strategic Management Journal, 15 (special issue), 63-84.

Jain, B. A., Kini, O. (1994). The post-issue operating performance of IPO firms. Journal of Finance, 1699-1726.

Khanna, T., Palepu, K. (1997). Why focused strategies may be wrong for emerging markets. Harvard Business Review, 75(4), 41-51.

Khan, A. M. Manopichetwattana. V. (1989). Innovative and non-innovative small firms: Types and characteristics. Management Science, 35(5), 597-606.

Kirzner, I. M. (1997). Entrepreneurial discovery and the competitive market process: An Austrian approach. Journal of Economic Literature, 35(1), 60-85.

Kogut, B., Zander, U. (1996). What firms do? Coordination, identity, and learning. Organization Science, 7, 502-518.

Lach, S. (2000). Do R\&D subsides stimulate or displace private R\&D? Evidence from Israel. Working Paper 7943, National Bureau of Economic Research, Inc.

Lee, B. (2002). The growth of venture businesses and policy recommendations. Regulatory Research 11, 2, 119.

Lerner J. (1999). The government as venture capitalist: the long-run impact of the SBIR program. Journal of Business, 72(3), 285-318.

MacMillan, I. C., Siegel, R., Narasimha, P. (1985). Criteria used by venture capitalists to evaluate new venture proposals. Journal of Business Venturing, 1(1), 119-128.

McMullen, J. S. Shepherd, D. A. (2006). Entrepreneurial action and the role of uncertainty in the theory of the entrepreneur. The Academy of Management Review, 31(1), 132-152.

Megginson, W. L., Weiss, K. H. (1991). Venture capitalists certification in initial public offerings. Journal of Finance, 46(3), 897-903. 
Mincer J. (1974). Schooling, experience and earnings. Colombia University Press: New York.

OECD (1997). Best practice policies for SMEs venture business policy in Korea and its implication. Paris: Publications Service.

Oliver, C. (1991). Strategic responses to institutional processes. Academy of Management Review, 16, 145-179.

Peneder, M. (2008). The problem of private under-investment in innovation: a policy mind map. Technovation 28(8), 518-530.

Podolny, J. M., Stuart, T. E. (1995). a role-based ecology of technological change. American Journal of Sociology, 100, 1224-1260.

Podolny J. M. (2001). Network as the pipes and prisms of the market. American Journal of Sociology, 98(4), 829-872.

Podolny, J. M. (1993). a status-based model of market competition. American Journal of Sociology, 98, 829-872.

Porter, M. (1980). Competitive Strategy Free Press, New York.

Ratajczak-Mrozek, M. (2012). Global Business Networks and Cooperation within Supply Chain as a Strategy for High-Tech Companies' Growth. Journal of Entrepreneurship, Management and Innoation, 8(1), 35-51.

Schultz, T. (1959). Investment in man: An economist's view. Social Service Review, 33(2), 69-75.

Spence, A. M. Michael, A. (1974). Market signaling: Informational transfer in hiring and related screening processes. Cambridge: Harvard University Press.

Spence, M. (1973). Job market signaling. The Quarterly Journal of Economics, 87(3), 355-374.

Stuart, T. E. (2000). Inter-organizational alliances and the performance of firms: a study of growth and innovation rates in a high technology industry. Strategic Management Journal, 21(8), 791-811.

Stuart, T. E., Hoang, H., Hybels, R. C. (1999). Inter-organizational endorsements and the performance of entrepreneurial ventures. Administrative Science Quarterly, 44(2), 315-349.

Suchman, M. (1995). Managing legitimacy: strategic and institutional approaches. Academy of Management Review, 20, 571-610.

Tan, W. C., Tay, R. S. (1994). Factors contributing to the growth of SMEs: the Singapore case. In Proceedings of the 5th ENDEC World Conference on Entrepreneurship, Singapore: 150-161.

Teece, D. J. (1996). Firm organization, industrial structure, and technological innovation. Journal of Economic Behaviour \& Organization, 31(2), 193-224.

Timmons, J. A., Bygrave, W. D. (1986). Venture capital's role in financing innovation for economic growth. Journal of Business Venturing, 1(2), 161-176.

Tuma, N. B. Hannan, M. T. (1984). Social dynamics: Models and methods. New York: Academic Press. 
Tushman, M. L. Rosenkopf, L. (1992). Organizational determinants of technological change: Toward a sociology of technological evolution. Research in Organizational Behaviour, 14, 311-331.

USSBA (1995). Foundation for a New Century, USA.

Utterback, J. M., O'neill, R. (1994). Mastering the dynamics of innovation: How companies can seize opportunities in the face of technological change. Boston: Harvard Business School Press.

Weick, K. E. (1996). Drop your tools: An allegory for organizational studies. Administrative Science Quarterly, 41(2), 301-313.

Zimmerman, M. A. Zeitz, G. J. (2002). Beyond survival: Achieving new venture growth by building legitimacy. Academy of Management Review, 27, 414-431.

\begin{abstract}
Abstrakt (in Polish)
Niniejszy artykuł bada, jakiego rodzaju zewnętrzne wsparcie jest pomocne dla inwestycji typu venture capital oraz dla rozwoju przedsięwzięć dotyczqcych nowych technologii. Praca ta korzysta z teorii sygnalizacji oraz metodologii wielokrotnej regresji oraz analizy przetrwania, wykorzystujqc dane panelowe dotyczqce przedsięwzięć powstałych w Korei. Wyniki pokazujq, ze współpraca z grupami biznesu oraz poświadczenie przez rzqd maja pozytywny wpływ na przyciagnięcie inwestycji typu venture capital, które przyspieszajq wzrost przedsięwzięć dotyczq̨cych nowych technologii. Praktyczna implikacja dla przedsiębiorców jest taka, że potrzebujq oni uzyskać strategiczne wsparcie od grup biznesu oraz rzq̨du.

Słowa kluczowe: tworzenie przedsięwzięć dotyczq̨cych nowych technologii, mały biznes, teoria sygnalizowania, venture capital, pierwsza oferta publiczna.
\end{abstract}

